\title{
Doe zelf eens normaal, communistische smeris! Een vergelijking van ontoelaatbaar taalgebruik in de parlementen van Nederland en Tsjechië
}

\section{No, You Act Normal, Communist Copper! A Comparision of Unaccetable Language in the Parliaments of the Netherlands and Czech Republic}

Pim van der Horst

\begin{abstract}
Impolite language has a firm place in political interaction. In this article the author will compare the use of impolite language in the parliaments of the Netherlands and Czech Republic and find out why impolite language is used in a political context, in what form and if there are differences between the use of unacceptable language in the parliaments of the Netherlands and Czech Republic. The article starts with an overview of the concept of linguistic (im)politeness and relevant research in the field and examines the influence of the political context on the use of impolite language by politicians. Furthermore, an overview of utterances of impolite language in the parliaments of the Netherlands and Czech Republic is given, in order to compare the use of unacceptable parliamentary language in both countries.
\end{abstract}

\section{Keywords}

pragmatics; linguistic impoliteness; parliamentary discourse; political discourse; politeness 


\section{Inleiding}

De uitspraak doe zelf eens normaal, waarmee minister-president Mark Rutte tijdens de Algemene Politieke Beschouwingen van 2011 reageerde op de woorden doe eens normaal, man van Geert Wilders, heeft veel stof doen opwaaien. Politici spraken hun afschuw uit over dit soort taalgebruik. Rutte reageerde later zelf op dit incident met de woorden: „[...] Wilders heeft gisteren mijn grenzen van fatsoen overschreden." De minister-president impliceert hiermee dat er voor taaluitingen fatsoensgrenzen kunnen gelden, dat deze grenzen overschreden kunnen worden en dat iedereen een eigen interpretatie aan deze grenzen kan geven.

Onbeleefd taalgebruik komt voor in alle lagen van de bevolking en in een groot aantal verschillende communicatieve situaties, van een directeur van een grote multinational die uit frustratie vloekt als hij tijdens het klussen met een hamer op zijn duim slaat, tot voetbalsupporters op de tribune van een stadion die de fans van de tegenstander gericht met grove taal tarten. Gelet op het universele karakter van onbeleefd taalgebruik komt dan ook niet als een verrassing dat zelfs in een relatief statige en formele omgeving als het parlement zo nu en dan onwelvoeglijke taal te horen is. Het is in dit verband interessant om te kijken van welke verwensingen en andere uitingen van onbeleefde taal parlementariërs zich bedienen en vooral waarom. Zijn het simpele uitingen van frustratie of zit er meer achter en dient onbeleefd taalgebruik in deze context ook een politiek doel? Om deze vraag te kunnen beantwoorden moet eerst worden vastgesteld hoe onbeleefd taalgebruik tot stand komt. Aan de hand van onderzoek uit het vakgebied van de taalkundige pragmatiek wordt in deel 1 kort uiteengezet hoe mensen tijdens hun onderlinge communicatie beleefd en onbeleefd kunnen zijn en wordt getracht om tot een definitie van onbeleefd taalgebruik te komen. In deel 2 wordt het begrip onbeleefd taalgebruik vervolgens in de context van het parlementaire discours geplaatst om te achterhalen welke rol conflictief taalgebruik in het politieke spel speelt.

Schelden, vloeken en andere vormen van onbeleefd taalgebruik zijn voor een groot deel cultureel bepaald. In Spanje speelt familie bijvoorbeeld een belangrijkere rol dan in Noord-Europa en verwensingen aan het adres van de moeder van een persoon zullen daarom in Spanje vaak als beledigender worden ervaren dan in Noord-Europa. Daarentegen bestaat in Noord-Europa weer een sterkere tendens om met ziekten te vloeken dan in andere delen van Europa. ${ }^{2}$ Het is daarom interessant om te kijken of er verschillen bestaan tussen de manier waarop politici onbeleefde taal gebruiken in het Tsjechische en Nederlandse parlement. In deel 3 zal dit aan de hand van enkele opmerkelijke voorbeelden uit beide parlementen worden geïllustreerd. Hierbij zal de nadruk worden gelegd op onbeleefd parlementair taalgebruik uit de laatste 20 jaar.

1 http://www.nrc.nl/nieuws /2011/09/22/wilders-tegen-rutte-doe-eens-normaal-man (3. 10. 2014).

2 Van Oudenhoven, Jan Pieter en Boele De Raad (2008): ,Eikels en trutten over de grens'. In: Onze Taal (9) 2008, blz. 228-231. 
In het derde deel zal tevens aandacht worden besteed aan de grenzen die aan het taalgebruik in het parlement worden gesteld. Deze grenzen worden geïllustreerd aan de hand van een beschrijving van de middelen die in het Nederlandse en Tsjechische parlement bestaan om tegen onbeleefd taalgebruik van parlementariërs op te treden, te weten de zogenaamde ,schrapbepaling' in Nederland (tot 2001) en een speciale parlementaire commissie in Tsjechië, en van de manier waarop deze middelen in de loop der tijd zijn ingezet.

Op basis van de drie voorgaande delen zal worden geconcludeerd welke rol onbeleefd taalgebruik in de politiek speelt of er verschillen bestaan in de manier waarop Nederlandse en Tsjechische politici zich de laatste 20 jaar onbeleefd hebben uitgelaten tijdens discussies in het parlement.

\section{Onbeleefd taalgebruik in communicatie: een pragmatische blik}

Onderzoek naar onbeleefd taalgebruik vindt zijn oorsprong in de eerste onderzoeken naar taalkundige beleefdheid van Brown en Levinson (1987), Lakoff (1973) en Leech (1983). Deze theorieën gaan uit van het coöperatieprincipe van Grice, dat omschreven kan worden als een soort stilzwijgende overeenkomst tussen gesprekspartners om bij het communiceren samen te werken door 4 maximes te respecteren (Baker et. al. 2013: 64):

- maxime van kwantiteit: de spreker geeft zoveel informatie als in de gegeven communicatieve situatie vereist is; niet meer en niet minder;

- maxime van kwaliteit: de spreker verschaft naar beste weten juiste informatie, en niet opzettelijk onjuiste informatie;

- maxime van relevantie: de gespreksbijdrage is relevant voor de vooruitgang van het gesprek;

- maxime van wijze: de spreker dient duidelijk, beknopt en geordend te spreken en vaagheden en dubbelzinnigheden te vermijden.

Brown en Levinson (1987: 5) beschouwen het coöperatieprincipe van Grice als een neutraal kader voor communicatie:

“The CP [Cooperative Principle] defines an 'unmarked' or socially neutral (indeed asocial) presumptive framework for communication, the essential assumption is "no deviation from rational efficiency without a reason'."

Volgens Brown en Levinson (1987: 95) is de belangrijkste reden om van de rationale effectiviteit af te wijken, en derhalve de maximes van Grice te overtreden, de poging om beleefd te handelen:

“[...] one powerful and pervasive motive for not talking Maxim-wise is the desire to give some attention to face. [...] Politeness is then a major source of deviation from such rational efficiency and is communicated precisely by that deviation." 
Iemand die zijn gesprekspartner bijvoorbeeld wil verzoeken het raam te openen, doet een verzoek dat de toehoorder misschien helemaal niet wil uitvoeren en loopt door het uiten van dit verzoek de kans dat de toehoorder hierdoor beledigd is. De spreker dient zijn verzoek derhalve zo te verwoorden dat hij de toehoorder zover krijgt om het raam te openen, zonder dat hij de toehoorder hierbij beledigt. Om dit te bereiken moet de spreker zijn verzoek omslachtiger, en derhalve minder efficiënt verwoorden, wat in tegenstrijd is met het coöperatieprincipe en de maximes van Grice.

Een ander zeer belangrijk concept in de beleefdheidstheorie van Brown en Levinson is het concept face. Deze term is afkomstig van Erving Goffman en wordt door hem als volgt gedefinieerd (Goffman 1955: 213):

"The term face may be defined as the positive social value a person effectively claims for himself by the line others assume he has taken during a particular contact. Face is an image of self-delineated in terms of approved social attributes- albeit an image that others may share, as when a person makes a good showing for his profession or religion by making a good showing for himself."

Het concept face verwijst derhalve naar het gevoel van eigenwaarde en de sociale identiteit van de gesprekspartners. Dit concept is terug te vinden in de Nederlandse uitdrukking je gezicht verliezen. In de theorie van Brown en Levinson dient een aanval op het gezicht van de gesprekspartner zoveel mogelijk afgezwakt te worden door het gebruik van beleefdheidsstrategieën. In de eerder genoemde communicatieve situatie met betrekking tot het openen van een raam kan de spreker zijn verzoek bijvoorbeeld langer maken en van meerdere beleefdheidsvormen voorzien om het gezicht van de toehoorder niet te beschadigen. Hij zou zijn verzoek bijvoorbeeld als volgt kunnen formuleren: sorry dat ik u stoor, maar zou u misschien het raam kunnen sluiten?

In de beleefdheidstheorie van Brown en Levinson is echter weinig ruimte voor onbeleefdheid. Het wordt enkel beschouwd als een pragmatisch falen om aan de beleefdheidsregels van een gesprek te voldoen, zoals blijkt uit onderstaand citaat (Brown en Levinson 1987: 95):

"[...] politeness has to be communicated, and the absence of communicated politeness may, ceteris paribus, be taken as absence of the polite attitude."

Leech (1983: 105) marginaliseert onbeleefdheid in zijn model door te stellen dat:

"[...] conflictive illocutions tend, thankfully, to be rather marginal to human linguistic behavior in normal circumstances."

Geleidelijk aan is echter de tendens ontstaan om onbeleefdheid te categoriseren als een mogelijk intentionele strategie in situaties waarin conflictief taalgebruik een grotere rol spelen en als een strategie die niet voldoende door voorgaande, op Grice gebaseerde beleefdheidsmodellen kan worden uitgelegd. 
De eerste pogingen om onbeleefd taalgebruik te beschrijven gebruikten echter vaak nog steeds de oude, traditionele beleefdheidskaders (Brown en Levinson) als uitgangspunt. Zo heeft Culpeper het kader van Brown en Levinson omgedraaid en van alle beleefdheidsstrategieën onbeleefdheidsstrategieën gemaakt. ${ }^{3}$ Het gebruik van traditionele beleefdheidsmodellen om onbeleefdheid te beschrijven kan echter problemen opleveren. Deze oude benaderingen zijn vaak gericht op afzonderlijke beleefdheidsstrategieën en onderzoeken onbeleefdheid niet in langere gedeeltes van het discours. In de beurten van gespreksdeelnemers kunnen meerdere onbeleefdheidsstrategieën voorkomen en deze kunnen over meerdere beurten verspreid zijn. Patronen van onbeleefdheid en de reacties daarop kunnen zich in de loop van enkele beurten ontwikkelen.

Een ander element dat in het traditionele onderzoek naar beleefdheid weinig tot geen aandacht heeft gekregen is de positie van de toehoorder. De traditionele onderzoeken waren meer gericht op de productie van beleefd taalgebruik door de spreker dan op de reactie van de toehoorder. Culpeper et al (2003: 1562) stellen echter dat de houding van de toehoorder van essentieel belang is, aangezien de reactie op een taaluiting veel kan zeggen over de manier waarop deze moet worden opgevat. Hirschová (2013: 237) noemt de interpretatie van de taaluiting door de ontvanger zelfs het belangrijkste element van onbeleefd taalgebruik.

Deze grotere nadruk op de positie van de toehoorder heeft geleid tot een verschuiving in het onderzoek naar taalkundige (on-)beleefdheid van traditionele, op Grice gebaseerde benaderingen naar een postmoderne benadering van (on-)beleefdheid waarin consensus bestaat over het feit dat het oordeel van de toehoorder de basis vormt voor beleefd en onbeleefd gedrag. Deze nieuwe postmoderne benaderingen hebben het rigide, duale model van spreker-toehoorder en afzonderlijke beurten ingeruild voor een dynamischer model waarin de verstandhouding tussen de gesprekspartners en hun sociale identiteit een grote rol spelen.

Een ander aspect dat in de beschrijving van onbeleefd taalgebruik een grote rol speelt, is de context. De groep waarin de taaluiting wordt gedaan bepaalt in grote mate de normen waaraan deze taaluiting dient te voldoen. Zo gelden er in een groep voetbalfans andere normen dan in een bejaardentehuis. Als iemand in een voetbalstadion schreeuwt en vloekt, zal dit eerder geaccepteerd worden dan als diezelfde persoon dit in een bejaardentehuis zou doen. De context en de groep waarin gesprekspartners hun taaluitingen produceren zijn daarom belangrijke factoren om vast te kunnen stellen of taaluitingen als onbeleefd beschouwd moeten worden.

Het laatste aspect van onderzoek naar onbeleefd taalgebruik dat aandacht verdient, is intentionaliteit. Hoewel het erg moeilijk is om in de hoofden van taalgebruikers te kijken en onderzoekers daarom op contextuele informatie moeten vertrouwen om de intentie van de taalgebruikers in te kunnen schatten, is het goed om te beseffen dat onbeleefd taalgebruik niet altijd expres wordt geuit. Het is zeer goed

3 Culpeper, Jonathan (1996): Towards an anatomy of impoliteness. In: Journal of Pragmatics 25, 349-367. 
mogelijk dat een spreker op een bepaald moment de beleefdheidsregels vergeet en de toehoorder(s) beledigt, zonder dat dat zijn/haar bedoeling was.

Dit beknopte overzicht van enkele belangrijke aspecten van onbeleefd taalgebruik toont aan dat taalkundige onbeleefdheid een complex concept is, waarin sociale identiteit, context en intentionaliteit een rol spelen. Het is derhalve geen verrassing dat Locher en Bousfield (2008:3) opmerken dat er eigenlijk geen overeenstemming is over wat onbeleefd taalgebruik nu precies inhoudt. Culpeper (2010: 3233) geeft van alle onderzoekers de meest uitgebreide definitie van onbeleefd taalgebruik, waarin de belangrijkste elementen, onder andere identiteit, context en intentionaliteit, verwerkt zijn:

"Impoliteness is a negative attitude towards specific behaviours occurring in specific contexts. It is sustained by expectations, desires and/or beliefs about social organisation, including, in particular, how one person's or group's identities are mediated by others in interaction. Situated behaviours are viewed negatively when they conflict with how one expects them to be, how one wants them to be and/or how one thinks they ought to be. Such behaviours always have or are presumed to have emotional consequences for at least one participant, that is, they cause or are presumed to cause offence. Various factors can exacerbate how offensive an impolite behaviour is taken to be, including for example whether one understands a behaviour to be strongly intentional or not."

\section{Onbeleefd taalgebruik in parlementaire context}

In de inleiding van een speciaal themanummer van Journal of Pragmatics over parlementair discours benadrukt Cornelia Ilie (2010: 879) het belang van het bestuderen van parlementair discours:

\footnotetext{
"In a period of increasing social paradigm shifts and political polarisations it has become increasingly important to examine the political agendas, the argumentation strategies, the deeper motivations and the ultimate goals of actors on the political stage in general, and in parliamentary institutions in particular. Political speech and action are tightly intertwined through the purposeful use of language, which, on the one hand, provides language users with frames for the expression of ideas and emotions, and, on the other hand, gets in its turn (re)shaped by these very ideas and emotions."
}

Taal is voor politici een machtig wapen dat wordt ingezet om politieke ideologieën en praktische strategieën te formuleren, politieke handelingen te verrichten en politiek leiderschap te legitimeren. Taal wordt door hen onder andere gebruikt om politieke macht te verkrijgen, om politieke macht te betwisten, om te strijden om politieke macht en om politieke macht te verdedigen en te consolideren. Politiek taalgebruik wordt primair gekenmerkt door confrontatie en competitiviteit, maar samenwerking en overeenstemming kunnen ook deel uitmaken van de politieke interactie in parlementen. Zo zijn er in het parlement bijvoorbeeld oppositiepartijen die de regerings- 
partijen aanvallen en politieke partijen die in een regering moeten samenwerken. Ilie (2003: 273) verwoordt dit als volgt:

\begin{abstract}
"Parliamentary debates presuppose, on the one hand, a spirit of adversariality, which is manifested in position claiming and opponent-challenging acts, and, on the other hand, a spirit of cooperativeness, which is manifested in joint decision-making and cross-party problem-solving processes in order to reach commonly accepted goals regarding future policies and suitable lines of action at a national level."
\end{abstract}

Aangezien de kans op het uiten van onbeleefde taal hoger is in conflictieve situaties, is het nuttiger om de aandacht op politieke confrontaties te richten. Čmejrková en Hoffmannová (2011: 96) merken op dat politici zich in dit verband vaak niet aan de elementaire beleefdheidsnormen houden en hun politieke tegenstanders aanvallen, hen persoonlijk beschuldigen, „op de man spelen”, hen ironisch uitlachen, hun tegenstanders provoceren, waarbij ze hun mate van expressiviteit en soms zelfs vulgariteit verhogen. Garcia Pastor (2008: 104) redeneert dat de onbeleefdheid in de richting van de andere debater (rivaal) niet anders geïnterpreteerd kan worden als een aanval op zijn of haar persoon omdat de deelnemers aan politieke debatten zich kandidaat hebben gesteld voor een bepaald ambt en elkaar in de strijd om het ambt continu proberen te beschadigen en te domineren.

In de politieke arena heiligt het doel de middelen. Conflict is een belangrijk element van het politieke spel en derhalve uiten politici in een politieke context zoals het parlement regelmatig onbeleefde taal om hun eigen politieke doelen of die van hun partij te kunnen verwezenlijken.

\title{
3. Onfatsoenlijk taalgebruik in het Nederlandse en Tsjechische parlement en de grenzen van het parlementair debat
}

Het feit dat onbeleefde taaluitingen tot op bepaalde hoogte bij het politieke spel horen, betekent niet dat alles maar gezegd mag worden in het parlement. In de loop der jaren is zowel in het Tsjechische als Nederlandse parlement getracht om onbeleefd taalgebruik aan banden te leggen.

Onder druk van nieuwe revolutionaire bewegingen zoals het fascisme en het communisme werd de sfeer in Nederland in het interbellum steeds grimmiger. Regelmatig demonstreerden arbeiders en er waren regelmatige opstootjes tussen extreemlinks en extreemrechts. Deze ontwikkelingen hadden ook invloed op de sfeer in de Tweede Kamer, waar debatten steeds vaker ontspoorden. Vooral de communisten lieten hun antidemocratische mening op niet mis te verstane wijze horen. Zo merken Bootsma en Hoetink (2006: 25) op dat de communisten in 1933 openlijk hun steun voor de muiters op het marineschip De Zeven Provinciën uitspraken.

Om het ondemocratische geluid in de Kamer te onderdrukken stelden de confessionele en liberale fracties in de Kamer voor om het Reglement van Orde van de 
Tweede Kamer aan te scherpen. Ten eerste om de waardigheid van het parlement te herstellen en ten tweede om te voorkomen dat antidemocratische parlementsleden hun immuniteit zouden gebruiken om strafbare, gezagsondermijnende uitlatingen te doen waarvoor ze niet vervolgd konden worden. In het kader van deze aanscherping werd de zogenaamde „schrapbepaling” in het Reglement opgenomen. Deze bepaling stelde de voorzitter van de Kamer in staat woorden uit de officiële verslagen van de Staten-Generaal te schrappen of deze door toelaatbare woorden te vervangen. Volgens Bootsma en Hoetink (2006: 14) werd hierbij vooral gedacht aan twee categorieën ontoelaatbare uitlatingen: beledigingen van de Kroon, een Kamerlid of minister en gezagsondermijnende opmerkingen. Op deze manier kon uit officiële documenten worden opgemaakt wanneer de fatsoensnormen van de Tweede Kamer werden overschreden.

Het gebruik van de schrapmaatregel was vanaf het begin onderwerp van discussie. Vooral de communisten zagen de bepaling als een poging om hen de mond te snoeren. Daarnaast gingen de media vanaf de jaren dertig een steeds grotere rol in de politiek spelen. Vanaf de jaren dertig werden sommige debatten rechtstreeks op de radio uitgezonden en vanaf 1955 zelfs op de televisie. Daarnaast was de geschreven pers vanaf 1940 steeds minder terughoudend met het afdrukken van woorden die vanwege hun opruiende karakter geschrapt waren.

Dankzij de technologische ontwikkelingen en een vrijere mentaliteit bij de pers gingen er in de loop der tijd steeds meer stemmen op om de schrapbepaling als sanctie te verwijderen. Vooral vanaf 1993, toen er begonnen werd met het rechtstreeks en ongecensureerd uitzenden van het vragenuurtje rees de vraag of het wel zinvol was om uitlatingen en woorden te schrappen als deze toch bij het brede publiek bekend zouden worden. In 1993 werd nog besloten om de bepaling uit historisch besef te handhaven, maar op 5 juli 2001 viel het doek definitief en werd de bepaling opgeheven. Vanaf dat moment worden alle gedane uitspraken van de parlementsleden integraal in de Handelingen afgedrukt. De voorzitter kan nu alleen ingrijpen door een parlementslid het woord te ontnemen of deze tot de orde roepen (artikel 58 en 59 van het Reglement van Orde). Het is hierbij belangrijk om te vermelden dat de voorzitter besluit of er ingegrepen wordt. De persoon van de voorzitter en diens politieke kleur zijn derhalve van invloed op de mate waarin tegen onbeleefde taaluitingen wordt opgetreden.

In de loop der jaren zijn verschillende soorten uitlatingen geschrapt en parlementair ontoelaatbaar verklaard. Bootsma en Hoetink (2006: 50-51) geven aan dat sinds 1934 het aanzetten tot een onwettige daad, het schenden van de geheimhoudingsplicht of het uiten van beledigingen, en in de parlementaire praktijk ook beschuldigingen, xenofobe, godslasterende en politiek gevoelige opmerkingen of gewoonweg scheldwoorden als onparlementaire taal zijn beschouwd. De eerste twee categorieën zijn schaars. Er is in het bestaan van de schrapbepaling van elke categorie slechts één voorbeeld bekend. Het merendeel van de schrappingen betreft beledigingen en beschuldigingen, waarbij beschuldigingen aan het adres van bewindslieden, de Kamervoorzitter en de Kamer als geheel als bijzonder ernstig werden beschouwd. Het beledigen van een bevriend staatshoofd was zelfs bij wet verboden. 
Een kijk op alle schrappingen tijdens het bestaan van de schrapbepaling tussen 1934 en 2001 leert ons dat de Kamervoorzitter het vaakst heeft ingegrepen bij uitlatingen van extreemlinkse en extreemrechtse partijen: de Communistische Partij (183 keer, 39,6\% van alle schrappingen), de NSB (76 keer, 16,6\%) en de Revolutionair-Socialistische Arbeiderspartij (61 keer, 13,3\%) ${ }^{4}$ Hierbij dient te worden opgemerkt dat alle partijen in het parlement wel eens berispt zijn, zei het in mindere mate dan de drie genoemde partijen. Bovendien blijkt uit het dossier van de schrappingen dat het overgrote deel in de periode 1934-1938 heeft plaatsgevonden, niet geheel toevallig de hoogtijdagen van de NSB en de Communistische Partij. Vanaf de jaren vijftig neemt het gebruik van de schrapbepaling dramatisch af en wordt deze vooral nog ingezet bij het onconventionele geluid van de Boerenpartij en later bij xenofobe uitlatingen van de Centrumdemocraten/Centrumpartij.

De opkomst van Pim Fortuyn en diens politieke partij LPF in 2002 en de toetreding van de PVV van Geert Wilders tot de Tweede Kamer in 2006 hebben geleid tot vernieuwde ophef over het taalgebruik in de Kamer. Uitlatingen als ,kopvoddentaks', ,de boom ingaan' en ,knettergek' als kwalificatie voor een minister hebben tot verontwaardiging geleid. Zo riep het Nederlands Dagblad op 29 december 2011 op om ,van de Kamer geen stamtafel te maken ${ }^{5}$. Politici van andere partijen laten zich echter ook niet onbetuigd. Zo schold Jan Marijnissen minister Koenders in 2009 drie keer uit voor ,flapdrol' en noemde voormalig Kamerlid Rita Verdonk toenmalig minister van Financiën Wouter Bos een ,leugenaar' en ,draaikont'.

Welke bewoordingen er voor de onbeleefde taaluiting worden gebruikt, is tot op zekere hoogte niet belangrijk. Verwensingen zijn er altijd al geweest en de taal in het parlement is erg tijdsgebonden. Bootsma en Hoetink (2006: 57) geven aan dat tot eind jaren zestig het woord ,brutaal' te direct was, een spreker het tot eind jaren vijftig niet over ,onzin' mocht hebben en de woorden ,schandalig' of ,schandelijk' tot 1990 niet werden getolereerd. Het is onmogelijk om alle onbeleefde taaluitingen uit het Nederlandse parlement te behandelen. In onderstaande tabel wordt een overzicht gegeven van enkele opmerkelijk uitspraken die de laatste jaren op de vloer van de Tweede Kamer hebben geklonken.

\begin{tabular}{llll}
\hline Jaar & $\begin{array}{l}\text { Wie uit onbeleef- } \\
\text { de taaluiting? }\end{array}$ & Wat is er gezegd? & Aan wie is de uiting gericht? \\
\hline $\mathbf{2 0 0 7}$ & Wilders (PVV) & „u bent knettergek” & $\begin{array}{l}\text { Minister Vogelaar van Wonen, } \\
\text { Werk en Integratie (PVDA) }\end{array}$ \\
\hline $\mathbf{2 0 0 8}$ & Graus (PVV) & $\begin{array}{l}\text { „mogelijk bent u een } \\
\text { beginnend lijder aan } \\
\text { alzheimer” }\end{array}$ & $\begin{array}{l}\text { Parlementslid Olmer (CDA) } \\
\mathbf{2 0 0 9}\end{array}$ \\
& Marijnissen (SP) & „flapdrol” & $\begin{array}{l}\text { Minister Koenders van Ontwikke- } \\
\text { lingssamenwerking (PvdA) }\end{array}$ \\
\hline
\end{tabular}

4 Zie Bootsma en Hoeftink (2006: 47).

5 https://www.nd.nl/nieuws/politiek/maak-van-de-kamer-geen-stamtafel.267366.lynkx (22. 4. 2015). 


\begin{tabular}{llll}
\hline Jaar & $\begin{array}{l}\text { Wie uit onbeleef- } \\
\text { de taaluiting? }\end{array}$ & Wat is er gezegd? & Aan wie is de uiting gericht? \\
\hline 2011 & $\begin{array}{l}\text { Geert Wilders } \\
\text { (PVV) }\end{array}$ & $\begin{array}{l}\text { „doe eens normaal, } \\
\text { man” }\end{array}$ & Minister-president Rutte (VVD) \\
\hline 2011 & $\begin{array}{l}\text { Geert Wilders } \\
\text { (PVV) }\end{array}$ & $\begin{array}{l}\text { „wat een zielig, mieze- } \\
\text { rig en hypocriet man- } \\
\text { netje bent u toch” }\end{array}$ & \\
\hline $\mathbf{2 0 1 4}$ & Özturk (DENK) & $\begin{array}{l}\text { „wie ben jij om mij } \\
\text { de loyaliteitsvraag te } \\
\text { stellen. Wie ben jij? Jij } \\
\text { moet eens goed na- } \\
\text { denken wie jij bent” }\end{array}$ & \\
& & & \\
& &
\end{tabular}

Tabel 1 Onbeleefd taalgebruik in het Nederlandse parlement: een beknopt overzicht

Artikel 13, lid 2 van het Reglement van Orde van het Tsjechisch parlement vermeldt dat er een tuchtprocedure gestart kan worden tegen parlementsleden die zich in het parlement of de senaat of in diens organen beledigend uitlaten over een parlementslid, senator, rechter, of een ander persoon die gerechtigd is aan vergaderingen in het parlement en wettelijke organen deel te nemen. Artikel 15, lid 1 vermeldt de straf die in dit geval kan worden opgelegd: de verplichting om binnen de gestelde termijn en op de vastgestelde manier excuses voor de ongepaste uitspraak aan te bieden of een boete ter hoogte van maximaal één maandsalaris van een parlementslid. ${ }^{6}$ Deze straf wordt vastgesteld door de commissie voor mandaten en immuniteit (mandátový a imunitní výbor, hierna „de commissie” genoemd). ${ }^{7}$ Welke uitlatingen als beledigend worden ervaren, wordt echter niet nader gespecificeerd en moet derhalve van geval tot geval worden bekeken.

Sinds diens oprichting in 1993 heeft de commissie zich meerdere malen moeten uitspreken over vermeende onfatsoenlijke uitlatingen van Tsjechische parlementariërs. Aanvankelijk moest de commissie voornamelijk optreden tegen uitlatingen van de extreem-populistische partij SPR-RSČ (Sdružení pro republiku - Republikánská strana Československa; Republikeinse partij Tsjechoslowakije). Tussen 1996 en 1998 heeft de commissie parlementariërs Krejsa en Sládek van deze partij op grond van rassenhaat ${ }^{8}$ hun parlementaire immuniteit ontnomen. Zover is het in alle andere gevallen van onbeleefd taalgebruik echter nooit gekomen. Soms wordt de onbeleefde taaluiting niet aan de commissie voorgelegd ${ }^{9}$ en als de commissie al een boete of verplichting tot het aanbieden van excuses oplegt, gaan de betreffende politici vaak in beroep tegen deze beslissing of besluit de commissie geen verdere stappen te nemen.

6 Zákon o jednacím řádu Poslanecké sněmovny (Wet inzake het Reglement van de Orde van het parlement)

7 Deze commissie besluit voornamelijk of de immuniteit van parlementariërs kan worden ontnomen, zodat ze strafrechtelijk kunnen worden vervolgd.

8 Gericht tegen Joden en Roma.

9 Parlementariërs moeten een geval van onbeleefd taalgebruik aan de commissie melden. De commissie handelt niet uit zichzelf. Probleem is dat parlementsleden onbeleefd taalgebruik in veel gevallen niet melden. 
De commissie heeft wat betreft het bestraffen van onbeleefd taalgebruik derhalve een vrij zwakke positie.

Net als bij de onbeleefde taaluitingen in het Nederlandse parlement is het op deze plaats praktisch onmogelijk om in te gaan op alle onbeleefde taaluitingen die in het Tsjechische parlement zijn geuit. In onderstaande tabel wordt een overzicht gegeven van enkele opmerkelijke onbeleefde taaluitingen uit de laatste jaren met informatie over de persoon die de taaluiting heeft geuit, de taaluiting zelf en tegen wie die uiting gericht was. Bovendien wordt aangegeven of de commissie de onbeleefde taaluiting heeft behandeld, welke straf er is opgelegd en hoe er op deze straf is gereageerd door diegene die de onbeleefde taaluiting heeft geuit.

\begin{tabular}{|c|c|c|c|c|c|}
\hline Jaar & $\begin{array}{l}\text { Wie uit } \\
\text { onbeleefde } \\
\text { taaluiting? }\end{array}$ & Wat is er gezegd? & $\begin{array}{l}\text { Aan wie is } \\
\text { de uiting } \\
\text { gericht? }\end{array}$ & $\begin{array}{l}\text { Reactie van } \\
\text { commissie }\end{array}$ & Vervolg \\
\hline 1999 & $\begin{array}{l}\text { Jiří Payne } \\
(\text { ODS })^{10}\end{array}$ & $\begin{array}{l}\text { „Pane ministře, } \\
\text { jste svině, jste } \\
\text { svině, jste } \\
\text { komunistická } \\
\text { svině“"11 }\end{array}$ & $\begin{array}{l}\text { Miroslav } \\
\text { Grégr } \\
(\text { ČSSD })^{12}\end{array}$ & --- & --- \\
\hline 2004 & $\begin{array}{l}\text { Zdeněk } \\
\text { Škromach } \\
\text { (̌́SSD) }\end{array}$ & $\begin{array}{l}\text { „Nezdržuj } \\
\text { a vypadni, ty } \\
\text { blbečku“13 }\end{array}$ & $\begin{array}{l}\text { Zdeněk } \\
\text { Doležal } \\
(\text { ODS) }\end{array}$ & --- & --- \\
\hline 2010 & $\begin{array}{l}\text { David Rath } \\
\text { (ČSSD) }\end{array}$ & $\begin{array}{l}\text { „Pravdepodobně } \\
\text { nejste úplně ve } \\
\text { stř́ízlivém stavu“14 }\end{array}$ & $\begin{array}{l}\text { Miroslav } \\
\text { Kalousek } \\
(\text { TOP 09) }\end{array}$ & $\begin{array}{l}\text { Rath krijgt } \\
\text { boete } \\
\text { opgelegd }\end{array}$ & $\begin{array}{l}\text { Rath verliest } \\
\text { beroep, moet } \\
\text { boete betalen }\end{array}$ \\
\hline 2011 & $\begin{array}{l}\text { Jiří Krátký } \\
\text { (ODS) }\end{array}$ & $\begin{array}{l}\text { „Kdo dělá v noci? } \\
\text { Kurvy a zloději“"16 }\end{array}$ & --- & $\begin{array}{l}\text { Krátký } \\
\text { krijgt boete } \\
\text { opgelegd }\end{array}$ & $\begin{array}{l}\text { Krátký betaalt } \\
\text { boete }\end{array}$ \\
\hline 2014 & $\begin{array}{l}\text { Miroslav } \\
\text { Kalousek } \\
\text { (TOP 09) }\end{array}$ & $\begin{array}{l}\text { „Komunistický } \\
\text { fizle }{ }^{17 ! “}\end{array}$ & $\begin{array}{l}\text { Zdeněk } \\
\text { Ondráček } \\
(\mathrm{KSČM})^{18}\end{array}$ & $\begin{array}{l}\text { Kalousek } \\
\text { krijgt boete } \\
\text { opgelegd }\end{array}$ & $\begin{array}{l}\text { Kalousek } \\
\text { in beroep; } \\
\text { commissie } \\
\text { schrapt boete } \\
\text { en excuses }^{19}\end{array}$ \\
\hline
\end{tabular}

10 Občanská demokratická strana (Democratische burgerpartij), liberaal-rechts georiënteerde politieke partij.

11 „Mijnheer de minister, u bent een varken, u bent een varken, een communistisch varken.”

12 Česká strana sociálně demokratická, Tsjechische sociaaldemocratische partij.

13 „Houd me niet op en donder op, idioot!”

14 „Waarschijnlijk bent u niet helemaal nuchter."

15 Centrumrechtse partij.

16 „Wie werken er 's nachts? Hoeren en dieven!”

17 „Communistische smeris!”

18 Communistische partij van Bohemen en Moravië.

19 Na overleg met juridische adviseurs van het parlement. 


\begin{tabular}{llllll}
\hline Jaar & $\begin{array}{l}\text { Wie uit } \\
\text { onbeleefde } \\
\text { taaluiting? }\end{array}$ & Wat is er gezegd? & $\begin{array}{l}\text { Aan wie is } \\
\text { de uiting } \\
\text { gericht? }\end{array}$ & $\begin{array}{l}\text { Reactie van } \\
\text { commissie }\end{array}$ & Vervolg \\
\hline $\mathbf{2 0 1 5}$ & $\begin{array}{l}\text { Andrej Babiš } \\
(\text { ANO })^{20}\end{array}$ & $\begin{array}{l}\text { "Tenhle lhár, } \\
\text { tenhle tunelár, } \\
\text { tenhle zloděj, } \\
\text { který nakradl } \\
\text { miliardy“21 }\end{array}$ & $\begin{array}{l}\text { Miroslav } \\
\text { Kalousek } \\
\text { (TOP 09) }\end{array}$ & -- & --- \\
& & & \\
\end{tabular}

Tabel 2 Onbeleefd taalgebruik in het Tsjechisch parlement: een beknopt overzicht

\section{Conclusie}

Zowel in het Tsjechische als in het Nederlandse parlement wordt regelmatig onbeleefde taal geuit. Conflict is een essentieel onderdeel van het politieke spel en dat uit zich onder andere in onbeleefde taal in de richting van politieke tegenstanders. Oppositiepartijen laten vaak een kritisch en scherp geluid in de richting van regeringspartijen horen en het is dan ook niet verwonderlijk dat zowel in Nederland als in Tsjechië het merendeel van de onbeleefde taaluitingen door oppositiepartijen worden geuit. Overigens speelt de menselijke factor ook een rol. Bepaalde politici hanteren vaker onbeleefde taal dan hun collega's of zoeken vaker het conflict, hetgeen ook tot onbeleefdere taaluitingen kan leiden. In Nederland doet Geert Wilders het meeste stof opwaaien met zijn taalgebruik. In Tsjechië uiten Miroslav Kalousek en David Rath regelmatig onbeleefde taal.

Taaluitingen in het parlement zijn echter niet alleen bedoeld voor de parlementaire consumptie. Door middel van hun uitlatingen proberen parlementariërs zichzelf te profileren en hun achterban buiten het parlement aan te spreken. Dit geldt vooral voor een politicus als Geert Wilders, die met zijn scherpe, duidelijke stijl van debatteren een grote aanhang heeft verworven.

Zowel in Nederland als in Tsjechië zijn in de reglementen van orde regels opgesteld die onbeleefd taalgebruik aan banden moeten leggen. In deze regels wordt echter niet duidelijk aangegeven wat er precies onder onbeleefd of ongepast taalgebruik wordt verstaan. Bovendien staat er op het uiten van onbeleefd taalgebruik in Nederland een zeer lage straf, namelijk het ontnemen van het woord en het terugnemen van de opmerking. In Tsjechië bestaat weliswaar de mogelijkheid om een boete op te leggen, maar politici kunnen hiertegen in beroep gaan en de commissie kan alleen een boete opleggen als gevallen van onbeleefd taalgebruik aan de commissie worden gemeld en dat gebeurt heel vaak niet omdat parlementariërs het niet de moeite vinden om vanwege de betreffende taaluiting een hele procedure te starten of omdat ze de taaluiting niet als beledigend interpreteren.

20 Nieuwe centrumrechtse partij.

21 „Deze leugenaar, die geld heeft weggesluisd, deze dief, die miljarden gestolen heeft.” 
Daarnaast maakt het politieke debat onderdeel uit van het brede maatschappelijke debat. De politieke cultuur is onderdeel van de nationale cultuur, die in de loop der tijd verandert. De nationale cultuur kent fatsoensnormen, die in de loop der tijd met de cultuur mee veranderen, hetgeen van invloed is op de mate waarin taalgebruik als onbeleefd wordt beschouwd, ook in de politiek. Deze tijdsgebondenheid is bijvoorbeeld terug te zien in het feit dat het woord ,brutaal' tot de jaren zestig niet werd geaccepteerd in het Nederlandse parlement, maar daarna wel. De parlementaire fatsoensnormen zijn derhalve onderhavig aan de nationale fatsoensnormen, die op hun beurt tijdsgebonden zijn. Dit geldt zowel voor Nederland als Tsjechië.

Er zijn tussen Nederland en Tsjechië geen aanzienlijke verschillen te vinden in het gebruik van onbeleefde taal in het parlement. Op het eerste gezicht lijkt het misschien dat er in Tsjechië expressievere onbeleefde termen worden gebruikt dan in Nederland, bijvoorbeeld „idioot”/"varken” in Tsjechië versus „flapdrol”/"knettergek" in Nederland, maar dit kan verklaard worden door een andere politieke cultuur in Tsjechië, waarin persoonlijke aanvallen scherper verwoord worden dan in Nederland. De communicatieve politieke functie van de onbeleefde taaluiting is in beide landen echter hetzelfde: je tegenstanders aanvallen en de belangen van jezelf en je eigen partij verdedigen.

\section{Literatuur}

BAKER, Anne E., DON, Jan, KEES, Hengeveld (red.) (2013): Taal en taalwetenschap. Wiley-Blackwell, Oxford.

BOOTSMA, P., HOETINK, C. (2006): Over lijken. Ontoelaatbaar taalgebruik in de Tweede Kamer. Boom, Amsterdam.

BOUSFIELD, Derek (2008): Impoliteness in Interaction. John Benjamins, Amsterdam and Philadelphia.

BOUSFIELD, Derek, LOCHER, Miriam (red.) (2008): Impoliteness in Language: Studies on its Interplay with Power in Theory and Practice. Mouton de Gruyter, Berlijn.

BROWN, Penelope, LEVINSON, Stephen C. (1987): Politeness: Some Universals in Language Usage. Cambridge University Press, Cambridge.

ČMEJRKOVÁ, S. en J. HOFFMANOVÁ (red.) (2011): Mluvená čeština: hledání funkčního rozpětí. Academia, Praag.

CULPEPER, Jonathan (1996): Towards an anatomy of impoliteness. In: Journal of Pragmatics 25, 349-367.

CULPEPER, Jonathan (2010): Conventionalised impoliteness formulae. In: Journal of Pragmatics 42 (2010), 3232-3245.

CULPEPER, Jonathan (2011): Impoliteness: Using Language to Cause Offence. Cambridge University Press, Cambridge.

CULPEPER, Jonathan (2012): (Im)politeness: Three issues. In: Journal of Pragmatics 44 (2012), $1128-1133$.

CULPEPER, Jonathan, BOUSFIELD, Derek, WICHMANN, Anne (2003): Impoliteness revisited: With special reference to dynamic and prosodic aspects. In: Journal of Pragmatics 35, 1545-1579. 
GOFFMAN, Erving (1967): Interactional Ritual: Essays on Face-to-face Behavior. Anchor Books, Garden City, New York.

HIRSCHOVÁ, M. (2013): Pragmatika v čestině. Karolinum, Praag.

ILIE, Cornelia (2010): Analytical perspectives on parliamentary and extra-parliamentary discourses. In: Journal of Pragmatics 42 (2010), 879-884.

ILIE, Cornelia (2003): Discourse en metadiscourse in parliamentary debates. In: Journal of Language and Politics 1 (2), 269-291.

LEECH, Geoffrey N. (1983): Principles of Pragmatics. Longman, London.

LIMBERG, Holger (2009): Impoliteness and threat responses. In: Journal of Pragmatics 41 (2009), 1376-1394.

LOCHER, Miriam A., WATTS, Richard J. (2005): Politeness theory and relational work. In: Journal of Politeness Research 1, 9-33.

VAN OUDENHOVEN, Jan Pieter, DE RAAD, Boele (2008): ,Eikels en trutten over de grens'. In: Onze Taal (9) 2008, 228-231.

WATTS, Richard J. (2003): Politeness. Cambridge University Press, Cambridge.

Drs. Pim van der Horst / pimhorstvd@gmail.com

Univerzita Palackého v Olomouci, Katedra nederlandistiky

Kř́žkovského 10, 77180 Olomouc, CZ 